\title{
Cartagena de Indias en la vitrina: configuración de imaginarios turísticos
}

\author{
Nidia Orozco Camacho ${ }^{1}$ \\ Universidad de Cartagena
}

\section{Resumen}

La presente investigación presenta los resultados de una investigación realizada en Cartagena de Indias sobre los imaginarios turísticos que construyen los comerciantes y las instituciones desde el proceso híbrido que se presenta en la exhibición de objetos que promueven a la ciudad, las estrategias discursivas utilizadas por los comerciantes para promocionarlos, y a partir de aquí, la forma como exteriorizan la ciudad que imaginan.

Palabras clave: ciudad, imaginarios, hibridación, discursos, monumentos, comercio.

\section{Abstract}

The present investigation presents the findings of an investigation carried out in Cartagena de Indias on the tourist imaginaries built by the merchants and the institutions from the hybrid process presented in the object exhibition promoting the city, the discursive strategies used by the merchants to promote them, and from here, the way they reveal the city they imagine.

Keywords: city, imaginaries, hybridization, speeches, monuments, trade.

\section{Introducción}

Los sujetos construyen e interiorizan la ciudad en donde viven. En el caso de Cartagena el ciudadano, y principalmente el comerciante, imagina una ciudad para el turismo que lo lleva a la configuración de un mapa de imaginarios híbridos que circulan en y sobre Cartagena. Abordar los imaginarios de la ciudad turística expresados en dichos discursos de promoción y venta de Cartagena que, además se

\footnotetext{
${ }^{1}$ Profesional en Lingüística y Literatura de la Universidad de Cartagena. Estudiante de Maestría en Lingüística y docente universitaria en las áreas de Psicolingüística, Teoría y Análisis Lingüístico, Análisis del Discurso y Semiolingüística.
} 


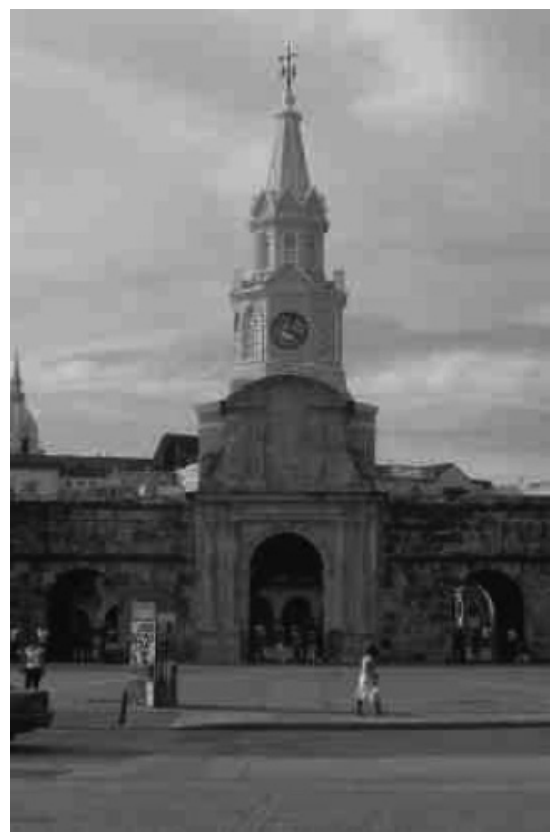

Waidy Miranda

La Torre del Reloj se ha convertido en imagen clave para promocionar a Cartagena. Las publicidades que se hacen de la ciudad la representan como la gran puerta que se abre para recibir al visitante y conducirlo por el centro histórico.

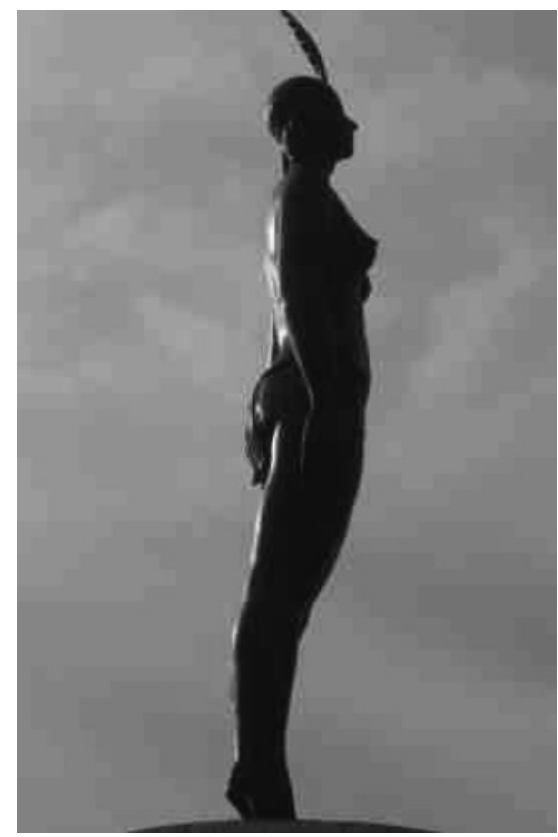

Waidy Miranda

La India Catalina es el icono por xcelencia de Cartagena, representa las raíces indígenas de la ciudad que enuncia una matriz tradicional, pero como en todo proceso cultural se dan hibridaciones.

apoyan en las imágenes y los objetos que los representan, permite contribuir al conocimiento de las complejidades, las luchas y las transformaciones que enfrentan los comerciantes del turismo en su concepción de ciudad desde la cotidianidad de sus prácticas comunicativas.

El presente análisis parte de un trabajo de campo realizado en galerías, tiendas y locales que venden artesanía en el centro histórico de la ciudad, el cual permitió establecer un corpus significativo de las prácticas discursivas, las colecciones e iconografías que configuran imaginarios turísticos en la ciudad. A través de entrevistas a trabajadores de agencias de viajes, entidades del sector privado que promocionan a Cartagena y de información recogida en revistas, el periódico El Universal, folletos promocionales, almanaques, entre otras fuentes, revisamos el discurso oficial institucional. Con el análisis del corpus se determinaron los recursos, las motivaciones y los referentes que dan cuerpo a tales imaginarios. 


\section{Bases conceptuales}

Las culturas urbanas son unas redes híbridas en las que se tejen diversidad de mundos donde se construyen identidades y diferencias colectivas. Aparece allí el ciudadano como figura reestructuradora y reconfiguradora que desde su construcción simbólica y su interacción con los demás imagina una ciudad para autorrepresentarse, compleja y creativamente, al mismo tiempo que se construye y la construye. La ciudad es, entonces, algo más que un lugar geográfico, con límites territoriales y normas gubernamentales. Como anota Armando Silva, "[es] una suma de opciones de espacios, desde lo físico, lo abstracto y lo figurativo, lo imaginario" (1997: 134).

En el contexto de este ser creativo del ciudadano vemos cómo en las ciudades las culturas se mueven entre diferentes matrices culturales que las constituyen: la tradicional (histórica, afroamericana, amerindia), la moderna (dominante-nacional siglo XIX, institucional y subyacente-internacional siglo XX), y la cultura mundo (del consumo y masmedias) (Ortiz: 1998), que aunque se pretendan ver distanciadamente se entrecruzan y producen intercambios e interacciones entre ellas, como se observa en la construcción de los imaginarios turísticos. Precisamente desde allí debemos definir algunos conceptos: lo popular y la cultura popular hay que considerarlos como una urdimbre tejida mediante las relaciones que los sujetos viven entre sí durante su configuración como seres sociales inmersos en dinámicas transformacionales que implican construcciones de nuevos espacios por donde circular y el mantenimiento de los mismos.

En nuestro contexto, como consecuencia del fenómeno de hibridación, encontramos los siguientes conceptos: 1) descoleccionar: los sujetos hacen colecciones mezclando elementos de lo culto, lo masivo y lo popular, y 2) desterritorializar: los espacios culturales pierden los límites y barreras geográficas con la globalización (cambios políticos y económicos) y la mundialización (dominio de la cultura que atiende a cambios sociales y a la configuración de un universo simbólico que engloba lugares y sociedades) (Ortiz, 1998), lo que permite a una cultura reapropiarse de objetos, signos, imágenes de otras culturas sin que se entienda como imposición exógena o robo.

Finalmente, en las actuaciones de los sujetos, una de sus formas de nombrarse como ser caribe y/o cartagenero se da a partir de la configuración de iconemas que identifican su ciudad con cierto tipo de imágenes. Los iconemas son una especie de iconos que suelen combinarse con otros manteniendo una representación más o menos 
constante, y a diferencia de los iconos propiamente dichos, nunca aparecen solos, siempre están en combinaciones variables, pero que mantienen ciertos rasgos "pertinentes" (Nieves, 2001: 54).

\section{Hibridación en iconografías, objetos y descolecciones}

En los locales comerciales se venden objetos que forman parte de lo que institucionalmente se ha establecido como patrimonio histórico y cultural de Cartagena, lo que muestra que los sujetos se acogen en cierta medida a lo institucional, pues le sirve de fuente para armar su discurso. Pero éste tendrá variaciones según el sujeto que lo produzca. Veamos cómo se presentan los objetos en los locales estudiados.

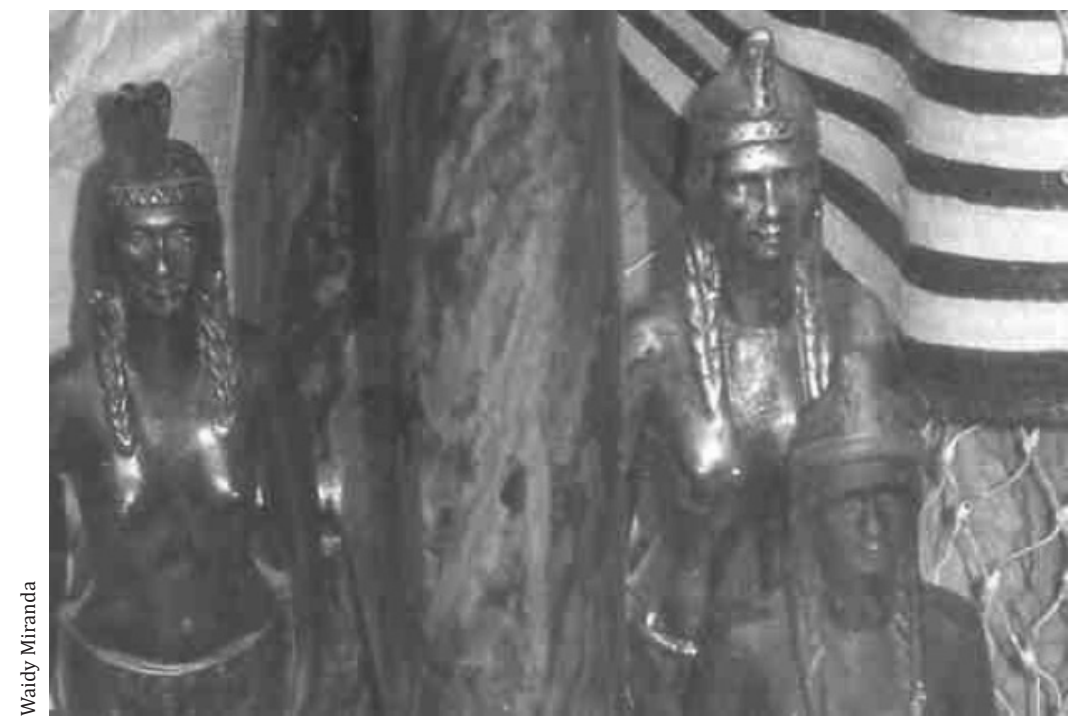

Réplicas de la India Catalina en una tienda de artesanías.

\section{Las "indias catalinas"}

La India Catalina es el icono por excelencia de Cartagena. Representa la raíces indígenas de las ciudad que enuncia una matriz tradicional, pero como en todo proceso cultural se dan hibridaciones. Dicha enunciación se hace a través de una herramienta de la matriz moderna (sugerencia de monumentos que invitan a la rememoración de los orígenes) y su exhibición se hace en un lugar que oscila entre lo museístico de lo moderno y la vitrina atrayente de la "cultura mundo", la tienda de artesanías.

Las réplicas encontradas en los locales están hechas en materiales (barro, cerámica) y modos de fabricación artesanal, la cual es destacada por los comerciantes como el trabajo propio de la región. 
Sin embargo, la mayoría de las veces son fabricadas en hornos industriales siguiendo un patrón establecido que se trabaja en series, característica propia de una "ola moderna" (Toffler, 1986). Algunas están pintadas semejando el color del monumento "original", el bronce; otras están pintadas de dorados, por lo cual da la impresión de que son de oro. Suelen encontrase también en postales, llaveros, camisetas de "cotton USA" o "made in China" (objetos vehiculizadores de la "cultura mundo"), y otras veces combinadas con otros iconos como las réplicas de los Zapatos Viejos y de las murallas, configurando iconemas de Cartagena.

Las réplicas de la India Catalina son de los objetos más promocionados y vendidos. Las ubican en un lugar visible de los locales comerciales, a veces al lado de las réplicas de las murallas y de los Zapatos Viejos y/o de la Torre del Reloj. En su puesta en conjunto el comerciante las combina con otros objetos que hacen parte de la "cultura mundo", como camisetas de Hard Rock Café o de las que promocionan a Colombia. Los cuadros que promocionan a la ciudad desde estas réplicas hablan de la historia de Cartagena atendiendo a un uso moderno de la Historia desde la cual se pretende preservar los monumentos de las transformaciones que sufre constantemente la ciudad. Por esta razón, cuando los comerciantes venden las "indias catalinas", cuentan brevemente la historia del personaje histórico acogiéndose al discurso oficial institucional.

\section{Las “torres del reloj”, los "zapatos viejos" y las "murallas"}

La Torre del Reloj (o Reloj Público), como comúnmente se conoce a la Boca del Puente, se ha convertido en imagen clave para promocionar a Cartagena. Es usual en las publicidades que se hacen de la ciudad para el resto del país y del mundo ${ }^{2}$ representarla como la gran puerta que se abre para recibir al visitante y conducirlo por el centro histórico o "ciudad vieja". Los comerciantes del turismo promocionan la Torre del Reloj en sus locales a través de réplicas en cerámica con sus colores típicos, amarillo con blanco, y se les puede ver formando iconemas con las murallas. Las réplicas de este monumento no se les encuentra con muchas variaciones, como sí ocurre con las "indias catalina"; los comerciantes prefieren ser lo más fiel posible al monumento original. Es muy usual encontrarlas en cuadros al lienzo y en hojas de carboncillo.

\footnotetext{
${ }^{2}$ Por ejemplo, Colombia Panorámica, de Villegas Editores; las revistas promocionales de Cartagena, como Convention and Visitors Bureau; en los planes de agencias de viajes, en televisión, etc.
} 
Con los Zapatos Viejos ocurre algo similar a lo del Reloj Público, las réplicas respetan el color original, marrón oscuro. En los locales no son tan promocionadas, como sí ocurre con las "indias catalinas" o con las réplicas de otros monumentos; sin embargo, son solicitadas por el turista.

Las murallas son el símbolo del fortalecimiento de Cartagena. Su valor cultural radica en la función cumplida durante el ataque de extranjeros y su preservación atiende a una rememoración propia de una mentalidad moderna que recuerda a la Cartagena valerosa de antaño que luchó por su supervivencia ante el asecho de los piratas que venían en busca de sus tesoros. Las murallas hacen parte del patrimonio cultural que representa la arquitectura militar de Cartagena y en reconocimiento de su valor cultural, en gran parte inculcado por los gobiernos, son promocionadas a través de imágenes por televisión, planes viajeros, almanaques, etc. En los locales comerciales es raro verlas solas; es más usual apreciarlas en iconemas con las "indias catalinas".

\section{Las "palenqueras"}

Son promocionadas como la raza propia de la región, representan la afrodescendencia de una matriz tradicional, de lo caribe-cartagenero, que necesita ser mostrado al resto del mundo. Las palenqueras también hacen parte de la iconografía turística de Cartagena. La forma como son promocionadas hace que cuando el turista, principalmente de otros países, llega a Cartagena quiera tomarse fotografías con las famosas palenqueras. Las réplicas, "ante eran traídas de otros lugares; ahora hay una fabrica en la ciudad", dice uno de los dueños de un local comercial del Centro Histórico. No sólo son elaboradas en cerámica, material que coincide con el periodo formativo de una cultura y que las hace parecer más tradicionales, sino también en un nuevo material llamado porcelanicrón. Los colores de sus vestidos, aparte de ser coloridos, como tradicionalmente se les identifica a las palenqueras, también presentan cítricos fosforescentes y neones que semejan un espectáculo de luces al mejor estilo discotequero.

En las réplicas los rasgos corporales de las palenqueras son deliberadamente exagerados: senos voluptuosos que algunas figuras tienen al descubierto, labios sobresalientes y colorados y gestos eróticos. En algunas réplicas aparecen con las piernas abiertas, con las

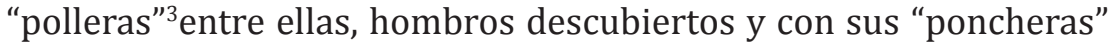

${ }^{3}$ En América meridional, nombre con el que se conocen las faldas que usan las mujeres. 
o "palanganas"4 en sus cabezas. En la mayoría de los casos aparecen con una sonrisa amplia que deja ver una blanca dentadura. Ahora también las hacen abrazando una botella de Tres Esquinas, ron de la región.

\section{Los sombreros vueltia'os}

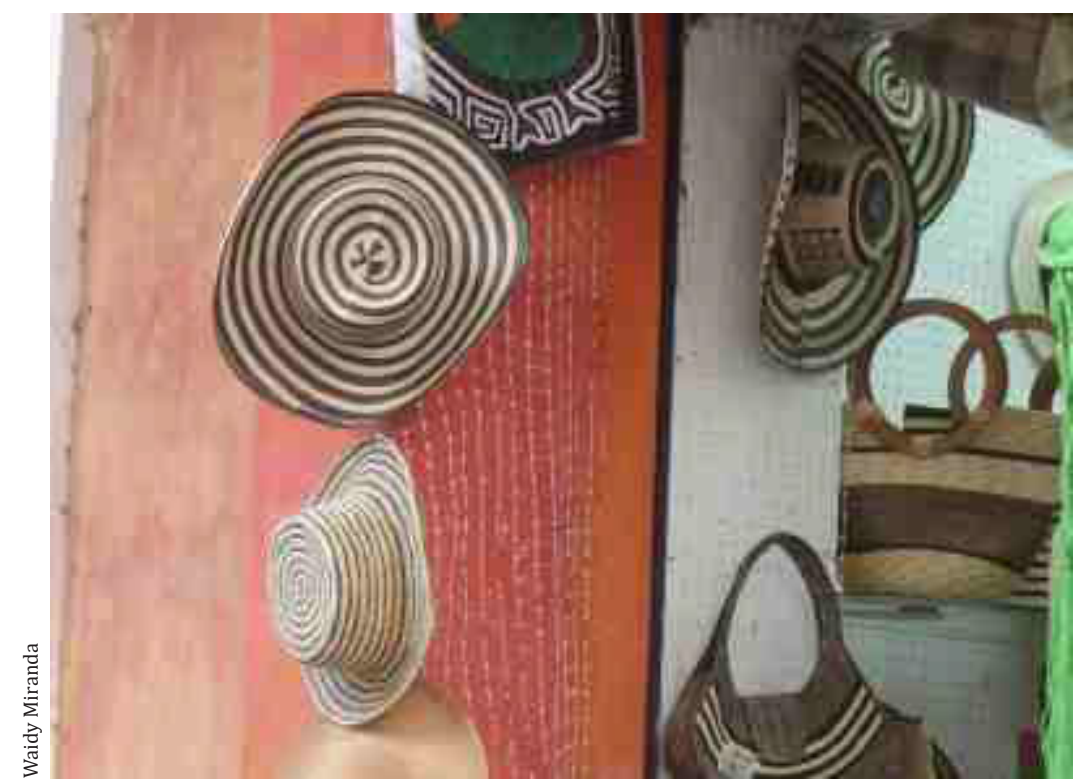

Objeto que representa la indumentaria del campesino-caribe. Los sombreros son elaborados a mano en un material natural llamado caña de flecha. Las galerías los promocionan como un objeto representativo del patrimonio cultural. Muchos de los locales en los cuales los venden están acondicionados como un museo desde el cual, al ser este un lugar propio de la matriz moderna de carácter dominante nacional, se pretende la preservación de lo tradicional en un espacio que se presenta como la memoria ciudadana que recuerda, como afirma Xibille, "los viejos tiempos artesanales [...] y donde todo podría conservarse para la memoria de los pueblos venideros" (2000: 15). Sin embargo, el local funciona también como espacio de la "cultura mundo" en el momento que se vuelve vitrina. El museo sufre una transformación dada por las exigencias actuales: no sólo preservar el valor cultural del objeto, sino también venderlo.

El sombrero vueltiao es el regalo obligado para las personalidades que arriban a Cartagena: Bill Clinton, ex presidente de lo Estados Unidos, le tocó ponerse el sombrero y terciarse una mochila

${ }^{4}$ Objetos donde las palenqueras llevan las frutas que venden. 
para sentir lo caribe-cartagenero. Hechos como este llevan a los comerciantes de los locales a utilizar a estas personalidades como gancho publicitario: se les toman fotografías con esta indumentaria $\mathrm{y}$ al momento de promocionar el sombrero recuerdan a los turistas que tal personalidad lo usó en su última visita a la ciudad.

\section{Las chivas}

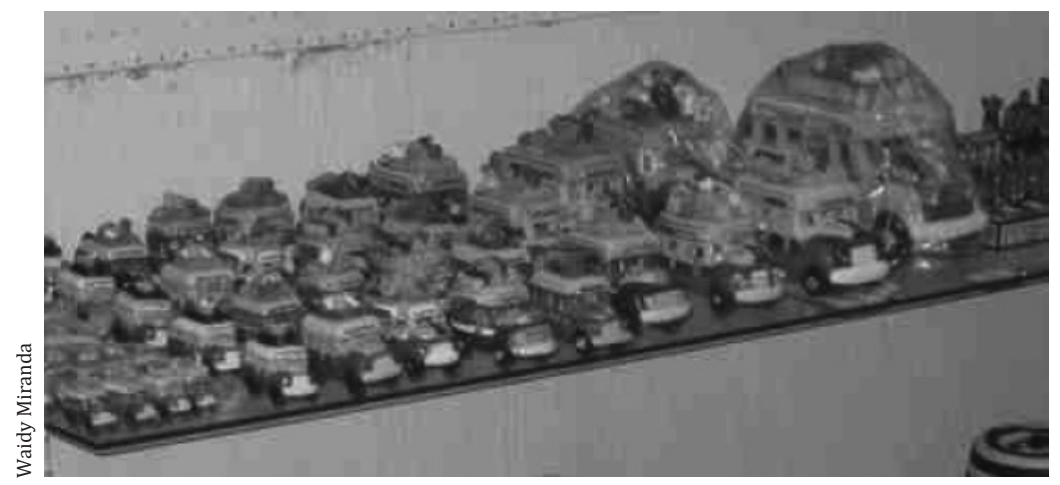

Cuando un turista llega a Cartagena no puede faltar dentro del plan vacacional la famosa "rumba en chiva", que consiste en un recorrido por el centro histórico de la ciudad. La chiva se promociona como "el típico bus cartagenero". Son coloridas, hechas en maderas y en la parte externa tienen dibujos alusivos a la ciudad: el Reloj Público, las murallas, las palenqueras, etc. Otras tienen dibujadas palabras que hacen alusión al lenguaje popular de la ciudad o calificativos propios de la cultura caribe-cartagenera como "la nojoda", "la heroica", "la quita sueño", "la melosa”, "la pechichona”, entre otras.

La desterriorialización, uno de los fenómenos presentes en el proceso de hibridación, se evidencia a través de la reapropiación de un vehículo originariamente utilizado en la región del interior de Colombia y que en Cartagena, sin ningún conflicto territorial, se presenta al turista como propio. En las fotos de chivas encontradas en las revistas a través de las cuales circula el discurso oficial institucional aparecen personas de raza negra con trencitas, trajes coloridos, gente que representa al "pueblo cartagenero".

Es común que en los locales estudiados algunos objetos sean adquiridos teniendo en cuenta el grado de representación con la ciudad (las replicas de palenqueras, de monumentos históricos, los cuadros de las calles de Cartagena, entre otros) atendiendo a una política de promoción de la misma por medio de imágenes inicialmente establecidas por entidades gubernamentales, pero que 
los comerciantes se reapropian de manera creativa, haciendo mezclas. Lo anterior da cuenta de la hibridación de las diferentes matrices y de la resignificación de los imaginarios populares, reiterándose de esta manera que las reproducciones de los sujetos populares no son reproducciones pasivas del discurso hegemónico, sino que ellos mismos demuestran la capacidad que tienen de apropiarse de los bienes que le sirven para una autorrepresentación.

\section{Camisetas, postales y llaveros}

A través de estos formatos de la "cultura mundo" circulan iconemas turísticos: playas, sol, palmeras, murallas, "indias catalinas", "zapatos viejos", palenqueras. Son los objetos más vendidos por los comerciantes informales, es decir, aquellos que poseen locales en la calle de las bóvedas y en las del Centro Histórico, distantes de donde se encuentran las reconocidas galerías. Los comerciantes que poseen "galerías de élite" no promocionan este tipo de objetos; prefieren "dejárselo a los locales populares".

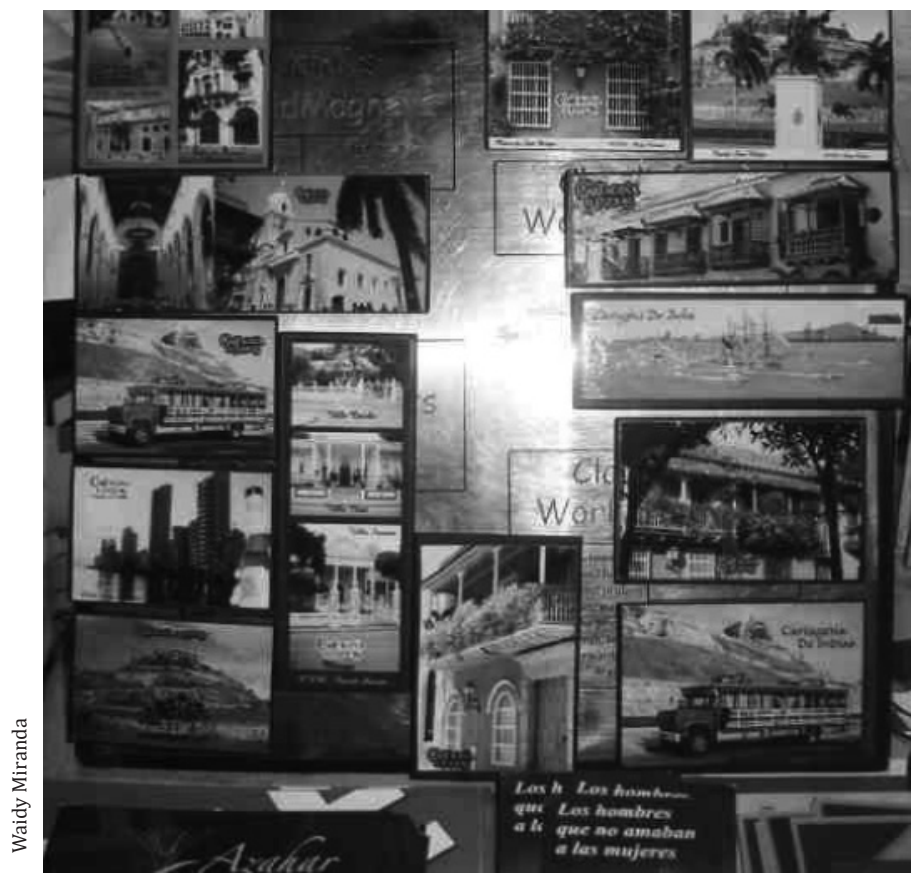

Postales en un local comercial de la ciudad.

Los llaveros son uno de los objetos más vendidos, pues es la manera más cómoda de "llevarse a Cartagena como recuerdo". Se les encuentra con figuras de la India Catalina, de los Zapatos Viejos, de palenqueras, etc. Por su parte, las postales son uno de los formatos más característicos de la "cultura mundo". A través de ellas se comunican 
sujetos de diferentes lugares y se dan a conocer aspectos de las culturas por medio de paisajes, monumentos representativos. Las que encontramos en los locales muestran imágenes de atardeceres de Cartagena: sol poniéndose en el horizonte del mar o muriendo en las murallas detrás de hermosas palmeras; otras, con la Torre del Reloj y al fondo la cúpula de la iglesia de San Pedro Claver. Otras, con las calles del Centro Histórico y casas con sus balcones llenos de hermosas flores.

Son muchos los objetos que se pueden encontrar en los locales estudiados y su puesta en escena permite apreciar la creatividad que tiene el comerciante para captar la mirada consumidora del turista en un espacio donde se relacionan el ciudadano, el turista, los objetos, los intereses, etc., a través del maquillaje, el secreto, la mentira, el juego de sentidos, los simulacros, las copias, los trasplantes, la apropiación, convirtiendo a la ciudad en el espacio perfecto para una cita entre culturas que pone en cuestión la concepción de autenticidad.

\section{Discursos de promoción}

La puesta en escena de los objetos requiere de unos discursos que los promocionen y despierten los sentidos del turista para que éste se decida a comprar. Para eso el comerciante se vale de algunas estrategias discursivas como la mentira y el secreto, que sirven de mecanismo de persuasión. Antes de revisar los discursos es necesario aclarar que la ubicación del local y su relación directa o indirecta con organismos gubernamentales influye en la producción de los discursos, razón que permite su clasificación de esta manera:

1. El discurso "oficial comercial formal" producido por galerías y tiendas consideradas de la élite que tienen un prestigio reconocido no sólo en la ciudad, sino en el resto del país y en otros países que las hacen "diferente" de las demás. Este discurso tiende a guardar más relación con el oficial institucional y los locales que lo enuncian apuntan a una concepción de museo moderna, donde lo que se exhibe hace parte de "una preservación de nuestra cultura caribeña y de Colombia en general", como señala una vendedora.

2. El discurso "no oficial comercial formal" se le atribuye al producido por los comerciantes cuyos locales se encuentran alrededor de las galerías de la élite, ya que éstos al ver la fuerte competencia que representan dichos locales procuran hacerse a un discurso que pueda competir con el de ellos. 
3. El discurso "no oficial comercial informal" es el usado por los comerciantes de los locales de Las Bóvedas y los que se ubican en el resto de las calles del centro histórico. Se le ha denominado así para establecer ciertas diferencias con el anterior, pues debido a que se encuentran retirados del resto de locales les de más libertad de crear y usar las estrategias discursivas para agradar al turista.

4. El discurso "oficial institucional", manejado por el gobierno, sus instituciones y además por entidades privadas, sirve de parámetro a los demás discursos, ya que cuenta con un reconocimiento a nivel nacional e internacional apoyado en libros de educación, revistas promocionales, planes viajeros, circulación por los medios masivos de comunicación, entre otros.

Veamos algunos ejemplos del funcionamiento de estos discursos. Una señora suiza compró varias réplicas de chivas para llevarlas como un recordatorio de la ciudad donde estuvo (Cartagena) después que la vendedora del local le dijo que ese bus era una de las "mejores muestras típicas de la región". De las cosas que llama la atención del turista son las artesanías", comenta un vendedor durante una entrevista realizada en un local de la calle de la Iglesia. A la hora de hablar del precio siempre resaltan su bajo costo para "la calidad de objeto que se va a llevar", afirma el comerciante. Sin embargo, algunas veces reconocen su alto costo, atendiendo a que no es tanto si se mira el trabajo: "Son un poquito caras, pero es que son muy trabajadas [...] claro que si es en "cash" [efectivo] le hacemos un descuento".

A los turistas se les vende la idea de que la mayoría de los objetos que observan son hechos por los indios de la región y los que no, son hechos por artesanos de los diferentes pueblos de Bolívar como San Jacinto, pueblo que se destaca por su variada artesanía. El vendedor omite que en algunos casos las artesanías son hechas por los mismos trabajadores del local o por sus dueños. Sólo en el caso de algunas artesanías que hacen los presos de la ciudad, dicen su procedencia. Mostrando sus pequeños baúles un vendedor dice: "son hechos por los presos de aquí, a ellos les enseñó un mexicano que estuvo dándoles un taller en la cárcel”. Decir que fueron los presos y no los artesanos los que elaboraron los baúles es usar la verdad como estrategias de venta (la provocación), ya que lo que quieren es tocar los sentimientos del cliente y hacer "una gran venta".

En los casos anteriores podemos observar el uso frecuente de estrategias discursivas como la mentira y el secreto. La mentira, en 


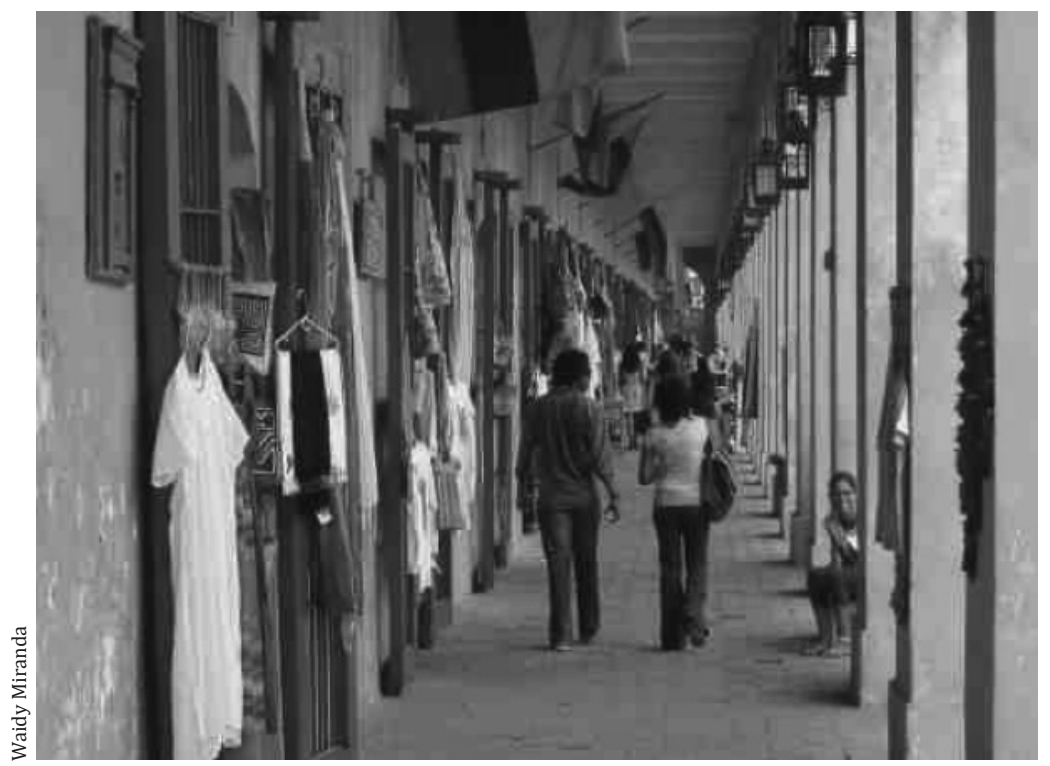

Muchos de los locales comerciales son el espacio perfecto para una cita entre culturas que pone en cuestión la concepción de autenticidad.

cuanto el comerciante da al turista una información como verdadera a sabiendas que la realidad es diferente, y el secreto lo usa porque muchas veces no quieren decirlo todo, y otras porque le conviene callar para lograr sus intereses. Los discursos que se han revisado pertenecen al discurso "no oficial comercial informal", que es donde se puede apreciar mejor el uso de esta estrategia discursiva. La mentira y el secreto son dos estrategias que en los discursos no se separan y ambas intervienen en la provocación del receptor (el turista).

Durante el desarrollo de esta investigación se realizó una visita a una entidad privada a la cual están vinculadas otras empresas del sector privado relacionadas con el turismo, con el fin de revisar sus estrategias y su discurso. Al preguntar por su objetivo al gerente ejecutivo se obtuvo el siguiente testimonio:

Nuestro objetivo principal es la promoción de Cartagena de Indias, para lo que tenemos en cuenta dos ejes: en un $35 \%$ uno de entretenimiento, es decir, el turístico; mostramos sol, playa, monumentos, restaurante, discotecas; y el otro eje, de un 65\%, es el de congresos, el especializado, donde promocionamos salones para conferencias, centros de convenciones, etc., claro, sin dejar de lado lo atrayente del paisaje cartagenero, su centro histórico, sus mejores restaurantes, etc. 
¿Qué hacemos?: primero identificamos el producto: Cartagena de Indias, y luego, lo ubicamos en un plano de promoción nacional o internacional. Si es nacional, lo que se busca es entretenimiento, así que procuramos incentivos: programas y concursos. El lugar indicado para promocionar es la playa. Si es internacional, lo que se promociona es lo cultural, el patrimonio histórico y le ofrecemos sedes para eventos.

En este discurso se deja ver claramente que para el sujeto del sector privado lo más importante es su economía, lo que puede lograr al promover a Cartagena, antes que una identificación de sí mismo con la cultura cartagenera. Sus propósitos y las estrategias que utiliza para lograrlos están bien definidos. Elabora deliberadamente los discursos que le servirán para vender su producto manteniendo una buena gramática y cuidando una limpieza del lenguaje condicionada por la forma en que es presentado, que no da espacio para la improvisación y la espontaneidad, como sí ocurre con el discurso que a diario deben realizar los comerciantes en los otros locales estudiados que, aunque tratan de seguir un patrón dado por el discurso institucional, mantienen ciertas reiteraciones tomadas de la cotidianidad que le brinda la posibilidad de hacer continuamente cambios permitidos por el carácter oral de su comunicación.

\section{Consideraciones finales}

En el "discurso oficial institucional" y en las imágenes que lo apoyan se dan también procesos híbridos que interrelacionan elementos de las tres matrices (tradicional, moderna y "cultura mundo"). Sin embargo, la matriz más presente es la moderna, vista en su afán de museización de lo que representa a Cartagena: sus monumentos, su legendaria historia, etc., reflejo de una conciencia de lo nacional que debe ser protegido de los acechos transformadores de la posmodernidad, para no perder los orígenes y tener qué mostrar al visitante.

Esa conciencia moderna está atravesada por elementos de la "cultura mundo" de los cuales el mismo sujeto hace uso: lógicas de consumo, vías de circulación (televisión, revistas publicitarias, postales, etc.), formatos industriales, entre otros, que le permiten conseguir su objetivo: hacer que consuman a Cartagena. Los sujetos que elaboran este discurso contribuyen a la configuración de Cartagena como vitrina atrayente, espectacularizan la ciudad a la manera de lo que Collin Rowe llama ciudad teatral, "[...] que se ofrece como una amalgama de iconos [...] que teatraliza la historia y el futuro" (citado por Xibillé, 2002: 15). En la espectacularización de la ciudad el gobierno 
cumple una función determinante, en tanto que lidera los procesos de promoción con un discurso que sirve de patrón al resto de los discursos aquí analizados. Es el gobierno quien se ha encargado de construir, en primera instancia, la imagen de Cartagena a nivel mundial.

El discurso oficial institucional se vale también de las estrategias de la mentira y del secreto para lograr sus intereses, pues, al momento de promocionar a la ciudad, oculta informaciones y cambia otras, apuntando a lo que Manuel Delgado denomina "la gran estratagema del maquillamiento", refiriéndose a la Barcelona de 1992, cuando se preparaba para los juegos olímpicos (Xibillé, 2002: 16). Esta estratagema se refiere a la manera como se muestra la ciudad: los mejores lugares, el mejor ambiente, lo cálido de la gente, lo soñado, en fin todo lo que puede ser agradable a los sentidos del extranjero, escondiendo lo feo, lo que puede parecer desagradable a la vista. Discursos como éste muestran que la lógica institucional, además de regirse por una conciencia moderna, se apega a las fuentes que le ofrecen la "cultura mundo", lo que evidencia los cambios de mentalidades que se están dando actualmente por los discursos híbridos. Las relaciones entre los sujetos populares y de la élite se hacen cada vez más evidentes: entrecruzamientos de matrices, intereses, motivaciones, etc.

Recorrer al mapa de los imaginarios turísticos de Cartagena implica ver una ciudad construida por una variedad de discursos, objetos e imágenes derivadas de la colectividad de los sujetos urbanos que a través de su creatividad hibridan hábitos, percepciones e historias, convirtiendo a la ciudad en un mercado simbólico que busca atraer miradas consumidoras y provocar la venta de la misma. La relación comerciante-turista y objeto-mirada se estructura en la concepción ciudad-vitrina, que funciona como el espacio donde éstos cobran sentido y se consolidan para dar paso a la creación de discursos que fortalecen la promoción de la ciudad y se construyen los imaginarios turísticos de Cartagena.

El comerciante, como ciudadano, busca que la ciudad sea representada de la mejor manera posible ante el resto del mundo, por lo que se vale de su realidad para promocionarla. La realidad le ofrece: lugares, objetos, sujetos, tiempos. Pero no basta con esto. Él sabe que los elementos cobran sentido gracias al uso que se les dé. La forma en que los elementos son representados mentalmente determina sus funciones en la ciudad. Vemos que en la configuración de Cartagena como ciudad turística se entrecruza lo simbólico con la realidad y que los imaginarios permiten los cruces de sentidos sociales. Lo imaginario le da cabida a la invención como recurso de los sujetos 
para crear significaciones: "[...] en la percepción de la ciudad hay un proceso de selección y reconocimiento que va construyendo ese objeto simbólico llamado ciudad; y que en todo símbolo o simbolismo subsiste un componente imaginario" (Silva, 1997: 91).

Este componente no sólo influye en la puesta en escena de los objetos, la configuración de imágenes y la hibridación de matrices, sino que ayuda a la articulación de los discursos que promocionan a Cartagena. El gobierno y las entidades privadas, por su parte, se valen de técnicas publicitarias y la elaboración de imágenes representativas de la ciudad que luego se configuran como icomemas turísticos para apoyar su discurso oficial. El comerciante también hace su inversión en la promoción de la ciudad. Para esto tiene en cuenta el trabajo del gobierno. Sin embargo, el comerciante transforma y resemantiza ese discurso, hasta amoldarlo a sus intereses, para lo que se vale de elementos que vienen del componente imaginario.

El mapa de los imaginarios turísticos refleja las luchas de sentido y de poder presentes en todo campo cultural. En este caso el campo es el turismo en Cartagena, donde cada sujeto que lo constituye busca la forma de establecerse dentro del mercado promocional, evidenciando luchas por sobresalir, por ganar prestigio, por vender más y garantizar su permanencia en el campo. Esto se aprecia en hechos como el que algunos locales se hagan a determinados objetos, porque una de las más prestigiosas galerías de la ciudad los posea. El discurso también varía de acuerdo a los intereses, lo que hace posible la configuración de los cuatro discursos aquí presentados.

Lo imaginario condiciona la percepción que los sujetos tienen de la ciudad y les permite crear eso de que carecen: crean imágenes, hacen iconemas, juegan con el lenguaje, inventan discursos y modifican otros, contribuyendo a la elaboración de relatos de la cotidianidad. En la cotidianidad de los comerciantes del sector turístico impera, como en la vida cotidiana suramericana, una "sobreestimación exhibicionista", es decir, un afán por mostrarse y mostrar la ciudad, de hacer que el turista consuma lo que ha ofrecido: tradiciones, imágenes, identidad. Esto pone en escena al ciudadano como sujeto imprescindible de y para la ciudad que recorre performativamente, es decir, haciendo transformaciones en los modos de vida, en las formas de comunicarse y en las formas de pensar su ciudad.

Como señalábamos, el ciudadano no sólo recibe este nombre porque sea parte de una ciudad, sino también por establecer relaciones con las lógicas del mercado utilizando formas para mostrarse, 
promocionarse y venderse que hacen parte de los formatos industriales de la "cultura mundo" (medios de comunicación, tarjetas de presentación y otros estereotipos de consumo) y le permiten ofrecerle a Cartagena al turista de una forma diferente. En su puesta en conjunto se muestra la transversalidad que permite la hibridación, donde monumentos que hacen parte de una matriz moderna son elaborados con materiales que recuerdan una tradición artesanal (cerámica) y se presentan en formatos de una "cultura mundo" (tiendas y galerías), es decir, vía "shopping", en la que el mejor espacio para que sean consumidos y vendidos es la vitrina. Ventana que sirve para que el comerciante se muestre y el turista lo mire. La vitrina es un espacio de dramatización que sirve para que el ciudadano comprenda, a través de la mirada de los visitantes, cómo se ha proyectado y cómo ella quiere ser vista (Cfr., Silva, 1997).

\section{Bibliografía}

Benach, Nuria. (1999). "Políticas urbanas y producción de imágenes de la ciudad contemporánea: un análisis comparativo entre Barelona y Curitibia", en Carrión, Fernando y Wollrad, Dorte. (comp.). La ciudad, escenario de comunicación. Quito: FLACSO.

Escobar, Alberto et. al. (2001). Guía Cartagena. Bogotá: Gamma.

García Canclini, Néstor. (1990). Culturas híbridas. Estrategias para entrar y salir de la modernidad. México: Grijabo .(1995). Consumidores y ciudanos. México: Grijabo. Guía Turística Cartagena de Indias (2000). Revista promocional de Cartagena de Indias. Conventions and visitors boureau. Cartagena.

Nieves Oviedo, Jorge. (1997). "Acerca de la competencia sociocultural", en Historia y Cultura, $\mathrm{N}^{\circ}$ 5. Cartagena: Universidad de Cartagena. .(2001). "Imaginarios híbridos en el Caribe colombiano: iconografías y textualidades populares en Cartagena de In-dias", en Revista Agüai$t a, \mathrm{~N}^{\circ} 6$, Cartagena: Observatorio del Caribe Colombiano.

Ortiz, Renato. (1998). Otro territorio. Santafé de Bogotá: Convenio Andrés Bello.

Silva, Armando. (1997). Imaginarios Urbanos. Cultura y Comunicación Urbana. Santafé de Bogotá: Tercer Mundo. 3ra. ed.

Xibillé Muntaner, Jaime. (2002). "La metrópolis finisecular como espectáculo", en Revista de Estudios Sociales, N⒌ Bogotá: Universidad de los Andes 